\title{
Teaching Multi-Word Lexical Units in English for Specific Purposes
}

\author{
Tamara Polić* \\ PhD, Senior Lecturer, Traffic and Transport Department, Polytechnic of Rijeka, Croatia
}

*Corresponding Authors: Tamara Polić, PhD, Senior Lecturer, Traffic and Transport Department, Polytechnic of Rijeka, Croatia

\begin{abstract}
One of the most challenging aspects of teaching non-native speakers at the tertiary education level is to develop lexical competences, which include competences in reception and production of multi-word lexical units (MWLUs), especially in English for Specific Purposes (ESP), which uses them to a much greater extent than General English. MWLUs are primarily found in written language, which is of particular interest in this paper, since the teaching of ESP at the tertiary education level predominantly relies on written materials. MWLUs allow a sequence of modifiers placed in front of a head noun, without functional words assisting in the reception, i.e. in the recognition of semantic relations among them. This paper deals with the most widespread subcategory of MWLUs which we have named multi-noun lexical units (MNLUs), referring to MWLUs consisting exclusively of nouns. The paper offers proven comprehensive teaching and learning strategies to be used in the classroom, since the majority of works dealing with MNLUs approach them in a theoretical way, and just a few deal with MNLUs taking into account the Foreign Language Teaching - FLT (Glottodidactics) point of view.
\end{abstract}

Keywords: multi-word lexical units (MWLUs), multi-noun lexical units (MNLUs), English for Specific Purposes (ESP), technical English, lexical competences, teaching, learning strategies, reception, production, students

\section{INTRODUCTION}

People of various professions, such as merchants, seamen, statesmen, diplomats and many others have always been using languages of various occupations and professions. As Hutchinson and Waters (1987) put it, after the Second World War English becomes very important in the domain of economy owing to the economic predominance of the Unites States which made it international language of technology and commerce and established its status of lingua franca. Therefore, of all the languages for specific purposes, English for Specific Purposes (ESP) has been studied and learnt most. There is an immense number of scientists dealing with ESP, approaching it from various scientific angles, predominantly from the linguistics point of view. This paper adopts the approach of Foreign Language Teaching (Glottodidactics), focusing primarily on the learner and his/her needs, as long time ago established and suggested by Hutchinson and Waters (1987) and pursued later by other theoreticians and practitioners of ESP (cf. Carver 1983; Strevens 1988; Dudley-Evans and St. John 1998, and others). One of the basic aims of ESP teaching is how to help learners, non-native speakers, achieve lexical competences as similar to those of native speakers, which includes the reception and production of multi-word lexical units (MWLUs). Thus, the aim of this paper is to provide both theoretical background and practical guidelines for teaching and learning MWLUs in ESP, focusing on their subcategory for which we propose the term multi-noun lexical units - MNLUs (Cro. viseimenicki nazivi - VIN). While there is a substantial number of authors dealing with the theory of MWLUs (Halliday, 1985; Kvam, 1990; Stambuk 1997; Fabb, 1998; Huddleston and Pullum, 2010; Zgusta, 2010; Spiranec, 2011; Leech and Svartvik, 2013; Fercec and Lierman-Zeljak, 2015, and many others), the works approaching MWLUs and MNLUs from the FLT (Glottodidactics) point of view seem to be sporadic (Limaye and Pompian, 1991; Izquierdo and Bailey, 1998; Master 2003, 2004) tending to cease with Carrió Pastor in 2008. This paper revitalizes the problem of MWLUs, namely MNLUs, putting tertiary education teachers and students at the forefront, offering underlying strategies of teaching and learning MNLUs, thus alleviating the problem teachers of ESP are usually faced with: the absence of readily made material. 
The paper is based on technical English, namely English for Traffic and Transport Purposes (ETTP), wherefrom most of the examples have been taken, although MWLUs and MNLUs can be found in General English and in every field of science.

\section{THEORETICAL BACKROUND}

\subsection{Distinction Between Multi-Word Lexical Units and Multi-Noun Lexical Units}

The English language allows a sequence of modifiers, belonging to various parts of speech (adjectives, nouns, participles) to be placed in front of a head noun (which is the last one in the sequence), without functional words assisting in the reception, i.e. in the recognition of semantic relations among them (example taken from Kerekovic, 2012):

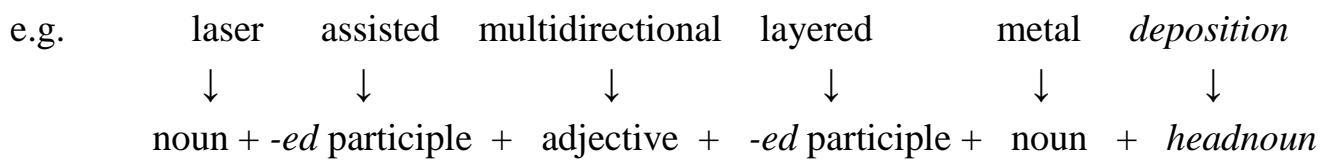

MWLUs are widespread in ESP, particularly in technical English which is extensively taught at the institutions of higher education. They are abundant especially in written technical English, i.e. in teaching materials (texts). In order to teach MWLUs learning strategies, we must first study them thoroughly, which is very challenging due to terminological inconsistency found in literature dealing with the topic. Spiranac (2011) lists various terms used for MWLUs including: composites, compounds, multi-word lexical units, multi-word expressions, multi-word lexemes, collocations, phrasal verbs, idioms, fixed sintagmas, phraseologisms and lexicalized phrases, to which we may add: multi-noun compounds (Newmark, 1985) and different-component compounds (Ferčec and Liermann-Zeljak, 2015). The term MWLU seems to prevail in literature over the others, so it has been chosen for this paper as well.

Regarding their definition, the most suitable one is offered by Kerekovic (2012), defining them as multi-word lexical sintagmas consisting of two or more words but functioning in a sentence as single lexemes.

However, the head noun in MNLUs can be premodified exclusively by nouns:

e.g. steam locomotive exhaust system design specifications

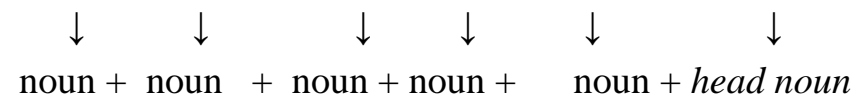

For this subtype of MWLUs we propose the term multi-noun lexical units (MNLUs) (Cro. viseimenicki nazivi - VIN) defining them in line with Kerekovic's (ibid.) definition of MWLUs as multi-noun sitagmas consisting of two or more nouns functioning as a single lexeme. This term unambiguously indicates the part of speech they consist of (nouns) and clearly distinguishes them from MWLUs as a hyperonymous category. Furthermore, depending on the number of constituent nouns, we propose terms: two-noun lexical unit (Cro. dvoimenicki naziv), three-noun lexical unit (Cro. troimenicki naziv), four-noun lexical unit (Cro. cetveroimenicki naziv), etc. Should the proposed terminology be accepted, the hitherto rather heterogeneous terminology used in both languages (English and Croatian) will be avoided in the future (cf. Polić, 2019).

Concerning examples of noun + noun sequences included in this paper, we are aware of the fact that in English grammar some of them may be considered compounds. For the purpose of this work and teaching, they will be subsumed under the term two-noun lexical units.

\subsection{Reception and Production}

Ministry of Science and Education of the Republic of Croatia (2006) defines language reception and production in the following way: "Reception implies understanding the linguistic message, while its transmitting implies linguistic production (...). Receiving messages involves listening and reading and mentally processing language content. The transmission of messages or language production is achieved by mental processing of content and shaping it by speaking or writing." (Translated in English by T. Polić).

In the same way that the miscellaneous terminology is used in literature for MWLUs and MNLUs, there are diverse terms for language reception and production, which is reflected in works dealing 
with MWLUs/MNLUs as well. While production is generally accepted as a term (Lindell, 2006; Shehata, 2008; Dziemianko, 2010; Spinner, 2013), reception (Nicholls and Mcgill, 1982; Milner and Milner Elrod, 1986; Shehata, 2008; Spinner, 2013) is also called interpreting/interpretation (Limaye and Pompian, 1991; Dziemianko, 2010; Pastor Góméz, 2010; Nakov, 2013) and decoding (Lewis, 1993; Master 2003, 2004). We opt for the terms reception and production considering their definitions and wishing to avoid terminological heterogeneity.

Works approaching MWLUs in glottodidactic context tend to neglect production, dealing mainly with reception, so one of the aims of this paper is to correct this injustice to the benefit of teachers and learners.

\section{Methodology}

This paper offers MNLUs teaching and learning strategies which have been used in the classroom for more than five years by the authoress, partially based on the proposals of previous authors, but mainly offering original approach, lexical exercise types and examples.

The suggested teaching and learning procedure starts with the introduction to MNLUs and their teaching and learning strategies (see subchapter 3.1), being subsequently divided in two main sections: reception (see subchapter 3.2) and production (see subchapter 3.3).

We start with the reception of two-noun lexical units, moving on to three and four-noun lexical units, observing the glottodydactic principle of gradual increase in complexity, i.e. the number of constituent nouns in a MNLU. Then we proceed with the production. The theoretical part is explained in Steps, followed by actual Tasks to be performed in the classroom. Note: the provided Tasks include just a limited number of illustrative MNLUs, while a teacher will find MNLU examples in the corresponding ESP he/she teaches.

\subsection{Introduction to MNLUs Teaching Strategies}

When starting teaching MWLUs, namely MNLUs to non-native speakers of English, the first step, according to Lewis (1993) is to arise student's awareness of their existence. Starting with two-noun lexical units which may be taken from General English (e.g. swimming pool, driving license, tennis player) is recommendable. Students are very motivated when asked to recall two-noun lexical units pertaining to everyday speech. That way they are introduced to the topic and the step towards ESP can be taken. Examples taken from the teaching materials are the best source, e.g. highway planner, gas turbine engine, airport road ground transportation. Next step is confronting MNLUs in English with students' mother tongue (L1), which helps a lot if they exist in their L1, unlike in Croatian. Since students are usually confused not knowing how to approach such noun sequences, they should be encouraged to verbalize the difficulties they encounter in reception of MNLUs. Their replies will reveal that they find it difficult to establish the semantic relationship among the constituent nouns. In other words, as Bartolic (1979) says, they do not realize "what refers to what". The teaching should start from the smallest units, i.e. two-noun lexical units, gradually proceeding to three-noun lexical units and four-noun lexical units. The more nouns, the more difficult the reception of MNLUs becomes. Hypothetically, the head noun may be premodified by an immense number of nouns, but in reality, it is very rare to find more than six nouns in a sequence. Since two, three and four-noun lexical units, as basic ones, are embedded in five-noun lexical units and lexical units composed of more than five nouns, this paper does not cover MNLUs consisting of more than four nouns, i.e. fournoun lexical units.

\subsection{Teaching and Learning MNLUs Reception Strategies}

\subsubsection{Two-Noun Lexical Units}

\section{Step1:}

Students should be taught that the last noun in the row is the head noun (Limaye and Pompian 1991, Izquierdo and Bailey 1989, Gacic 2009, and many others), being premodified by the noun preceding it. Learning this is the underlying basis to any further reception and production of MNLUs.

e.g. cylinder wall

control system

transport vehicle

International Journal on Studies in English Language and Literature (IJSELL) 
Immediately follows the task of identifying the head noun, such as:

Task 1: Circle (or underline) the head noun in the following two-noun lexical units:

hydrogen bomb

traffic corridor

railway network

Step 2:

Based on learners' knowledge of the final position of the head noun, students should be introduced to the task of choosing the correct paraphrase of two-noun lexical units. Master (2003) proposes multiple choice questions (MCQ) for the purpose. The correct paraphrase is the one that starts with the head noun.

Task 2: Choose the correct paraphrase of the following two-noun lexical units:

monitoring system

a) a monitor for a system

b) a system used for monitoring

Step 3:

The following step is establishing semantic fields to which MNLUs belong, i.e. determining "logical relationship between the modifying noun and the head noun" (Biber et al. 1999). While Biber et al. (1999) offer 15 semantic fields for everyday English (General English) two-noun lexical units (calling them noun + noun sequences), Bartolic (1979) who restricts her work to technical English offers somewhat different and seemingly shorter list consisting of 7 semantic fields, but including 5 subfields. Bartolic's follower Master in his article (2003) and grammar (2004) intended for non-native speakers of English studying science, medicine and technology takes a glottodidactic approach adopting and adapting Bartolic's (1979) classification of semantic fields by introducing the category of time (which is to be found in Biber et al. 1999 as well) and proposing more practical term for her professional engagement of a person or an organization naming it inventor/professional user.

Depending on the area, field and branch of study, every ESP teacher can choose among the semantic fields to be used in teaching, or even modify them according to the needs of the corresponding ESP he/she teaches. The following (Table 1) contains the proposed elements to be used for establishing semantic fields in technical English, based on Master's (2003) template:

Table1. Establishing semantic fields

\begin{tabular}{|l|l|l|}
\hline $\begin{array}{l}\text { TWO-NOUN LEXICAL UNIT AND } \\
\text { ITS PARAPHRASING }\end{array}$ & SEMANTIC FIELD & QUESTION \\
\hline $\begin{array}{l}\text { rubber tyre } \\
\text { (a tyre that is made of rubber) }\end{array}$ & 1) material & What is it made of/from? \\
\hline $\begin{array}{l}\text { spark ignition } \\
\text { (ignition started by means of sparks) }\end{array}$ & 2) operation principle & How does it work? \\
\hline $\begin{array}{l}\text { oil filter } \\
\text { (a filter } \text { used for } \text { cleaning oil) }\end{array}$ & 3) purpose & $\begin{array}{l}\text { What does it do? / What } \\
\text { is it used for? }\end{array}$ \\
\hline $\begin{array}{l}\text { road traffic } \\
\text { (traffic that } \text { takes place on the road) }\end{array}$ & 4) location & Where does it take place? \\
\hline $\begin{array}{l}\text { butterfly } \text { valve } \\
\text { (a valve that is } \text { shaped like } \text { a butterfly) }\end{array}$ & 5) shape/form/resemblance & What does it resemble? \\
\hline $\begin{array}{l}\text { Otto } \text { engine } \\
\text { (the engine that was invented by Nikolaus } \\
\text { Otto) }\end{array}$ & 6) inventor & $\begin{array}{l}\text { Who invented/discovered } \\
\text { it? }\end{array}$ \\
\hline $\begin{array}{l}\text { car factory } \\
\text { (a factory } \text { engaged in the production of } \\
\text { cars) }\end{array}$ & 7) professional engagement & $\begin{array}{l}\text { What is he/she/it engaged } \\
\text { in? }\end{array}$ \\
\hline
\end{tabular}

In order to determine the semantic field (Table 1, column 2) to which a particular MNLU belongs, students should ask themselves the questions (Table 1, column 3). It is important to draw students' attention to useful expressions to be used in paraphrasing (Table 1, column 1) such as: made of, by means of, (used) for, take place, shaped as / resembling, invented/discovered by, engaged in, and the like. 
Immediately follows the task in which students are asked to match the two-noun lexical units with the appropriate semantic filed, as proposed by Master (2004) and adapted to the field of traffic and transport:

\section{Task 3:}

Match the following two-noun lexical units with their corresponding semantic fields: freight train
transport enterprise
1) material
world production
2) operation principle
_ petrol station
3) purpose
tool holder
4) location
steel wheel
5) shape/form/resemblance
horse truck
6) inventor
diesel engine
7) professional engagement

butterfly valve

Step 4:

Paraphrasing MNLUs is the best strategy to learn how to receive (interpret/decode) them. It is very important to draw students' attention to the fact that nouns in a two-noun (or multi-noun) lexical unit may represent different meaning relations (Biber et al. 1999) with no clear indication to which semantic field they belong. As a result, the same two-noun lexical unit can be paraphrased in more than one way. Consider the example of a horse car:
a car that is used for transporting horses
- purpose
a car that looks like a horse
- shape / form / resemblance
a car that is drawn by (a) horse(s)
- operation principle

Only the context can eliminate the semantic ambiguity. Besides, in ESP the semantic ambiguity is eliminated by the fact that a great number of MNLUs are already listed in specialized dictionaries as fixed terms. Adding to it the assumed learner's knowledge of the professional/scientific field, semantic ambiguity will be substantially reduced and receiving MNLUs by paraphrasing will be much easier.

So, the next classroom activity is extended paraphrasing, a learning strategy leading to correct reception of MNLUs, as suggested by Limaye and Pompian (1991), Master (2003, 2004), and Carrió Pastor (2008). Paraphrasing enhances identifying semantic relations between the nouns in a two-noun lexical unit (or among more nouns in other MNLUs). As a rule, paraphrasing as a means of reception starts from the head noun leftwards, i.e. from right to the left (Gacic 2009), following the rule of inverse linearity (Skaric 1989):

$\begin{array}{cccc}1 & 2 & 2 & 1 \\ \underline{\text { maintenance }} & \underline{c r e w} & = & \text { a crew engaged in } \underline{\underline{\text { maintenance }}}\end{array}$

Task 4:

The following is the proposed classroom activity:

Paraphrase the following two-noun lexical units using Table 1:

e.g. fuel truck $=$ a truck used for transporting fuel

highway planner

water pump

cylinder wall

passenger train

steel cable 
Step 5:

Teaching translation possibilities in L1 is very important. Each language family and individual languages belonging to it have their own grammatical features, which is reflected in translating English MNLUs into them. In as plain language as possible, without using metalanguage, students should be introduced to basic linguistic patterns when trying to find translation equivalents in L1. The following will provide basic information about the possible ways of translating MNLUs in Croatian.

a) Translating in a way that a Croatian adjective takes over the semantic content of the English modifying noun (preceding the head noun):

English

hydrogen bomb

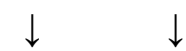

Noun Noun
Croatian

hidrogenska bomba

Adjective Noun

Since, according to Bartolic (1978) "the Croatian language has not formed all the possible adjectives which would correspond to the modifying nouns in English" Croatian resorts to other ways as well.

b) Croatian belongs to a family of South-Slavic languages. It is a highly inflected language in which grammatical morphemes express the grammatical category of case (Kovacevic, Palmovic and Hrzica 2009). In translating two-noun lexical units into Croatian, the head noun can appear in just one of the seven cases, i.e. genitive:

English

aircraft departure

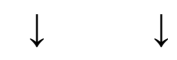

Noun Noun
Croatian

odlazak zrakoplova

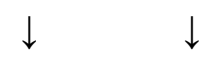

Noun Noun in genitive case

c) Translating using prepositions (Prep.). According to Stambuk (2005), there are four prepositions ( $s$, $z a, n a$ and $u$ ) appearing in Croatian equivalents, where the head noun becomes the first element in the Croatian MNLU. The following are the examples taken from English for Traffic and Transport Purposes:
English
Croatian
oil filter
filter za ulje
$\downarrow \quad \downarrow$
Noun Noun
Noun Prep. Noun

Every ESP teacher should find the rules of translating MNLUs in students' L1 and present them to his/her students. To check whether they have acquired the rules, the best way is to assign the translation task:

Task 5:

Translate the following two-noun lexical units into your mother tongue:

injector pump

street level

air filter

traffic management

\subsubsection{Three-Noun Lexical Units}

After the stage in which students have mastered the basic rules of receiving two-noun lexical units, they can be introduced to more complex and expanded MNLUs, following the rule of gradual increase in the number of premodifying nouns, i.e. three-noun lexical units.

In three-noun lexical units, as well as in all other MNLUs where the head noun can be premodified by a hypothetically endless number of nouns, the semantic relationship among the constituent nouns is not always obvious. Devoting his paper exclusively to three-noun lexical units (calling them three- 
part noun combinations) Kvam (1990) notices that the semantic links between the constituent nouns vary in strength, hampering their reception.

Step1:

In order to present in a systematic way the semantic links between the nouns, the authoress of this paper has designed the table of structural types of three-noun lexical units (Table 2), followed by explanation of semantic links and reception strategies.

Table2. Structural types of three-noun lexical units

\begin{tabular}{|c|c|c|}
\hline TYPE & THREE-NOUN LEXICAL UNIT & STRUCTURE \\
\hline Type A & vehicle guidance $\underline{\text { system }}$ & $\mathbf{1}+\mathbf{1}+\mathbf{1}$ \\
\hline Type B & gas turbine engine & $\mathbf{2}+\mathbf{1}$ \\
\hline Type C & airport car parking & $\mathbf{1}$ \\
\hline
\end{tabular}

Type $A$ is the simplest type of three-noun lexical units, being interpreted in the reversed order from the head noun. Each of the constituent nouns is a separate semantic unit for itself. Paraphrasing (by adding articles and prepositions) is facilitated by numbering the nouns (semantic units) above, showing the paraphrasing order, as Izquierdo and Bailey (1998), Master (2003, 2004) and Carrió Pastor (2008) do. Each semantic unit is additionally separated by vertical lines, as Bartolic (1978, 1979) does, while the numbers below the three-noun lexical unit indicate its structure:

$\begin{array}{llllll}1 & 2 & 3 & 3 & 2 & 1\end{array}$

$\underline{\text { vehicle } \mid \text { guidance } \mid \underline{\text { system }}=\mathrm{a} \underline{\text { system }} \text { for the guidance of vehicles }}$

$1+1+1$

TypeB. In the following example, as established by Bartolic (1979), the semantic link between the first two premodifying nouns gas turbine is stronger, while the third one engine is more loosely attached. The first two nouns gas turbine constitute an already lexicalized semantic unit (two-noun lexical unit), modifying together the head noun engine:

$2 \quad 1 \quad 2 \quad 1$

gas turbine $\mid$ engine $=$ the engine powered by a gas turbine

$2+1$

Reception starts from the head noun proceeding leftwards, and as Gacic (2009) emphasizes, we must not separate two-noun lexical units already established in a language as lexical (semantic) units and often already listed in dictionaries (e.g. power plant, traffic lights). Most of them are already considered compounds.

Analyzing the Brown University CorpusWarren (1978) established the higher incidence of Type B $(2+1)$ over the Type $C(1+2)$, which was confirmed later by Kvam (1990) as well.

In Type $C$, as seen in the following example, the head noun parking and the noun car premodifying it directly, present one semantic unit car parking, i.e. a two-noun lexical unit being premodified by a semantic unit airport which is more loosely attached.

$12 \quad 2 \quad 1$

airport $\mid$ car parking $=\mathrm{a}$ car parking at the airport

$1+2$

Task 1:

Determine the structural types of the following three-noun lexical units:

e.g. passenger $\mid$ road vehicle

$1+2$

access control building

port fuel injection

railway network segment

air purification system 
Task 2: Acquainted with the underlying structural parts of three-noun lexical units, knowing that the last noun is the head noun and that already lexicalized two-noun lexical units must not be separated, students can move on to paraphrasing the same examples from the previous task.

Task 3: The same as for two-noun lexical units, selecting the correct paraphrase using MCQ may follow as a next classroom activity. ESP teachers should be very inventing in designing them.

Choose the correct paraphrase of the following three-noun lexical units:

e.g. aircraft gas turbine

a) gas in the aircraft turbine

b) aircraft gas in the turbine

c) a gas turbine of the aircraft

\subsubsection{Four-noun lexical units}

The more nouns in a MNLUs, the more complex the structural types become. In line with the ideas offered by Bartolic $(1978,1979)$ and Fercec and Lierman-Zeljak (2015) this article offers the table of possible structural types of four-noun lexical units (Table 3). There are five basic structural types, named for this purpose $\mathrm{A}, \mathrm{B}, \mathrm{C}, \mathrm{D}$ and $\mathrm{E}$, two of them having subtypes, $\mathrm{D}_{1}$ and $\mathrm{D}_{2}, \mathrm{E}_{1}$ and $\mathrm{E}_{2}$ respectively.

Table 3. Structural types of four-noun lexical units

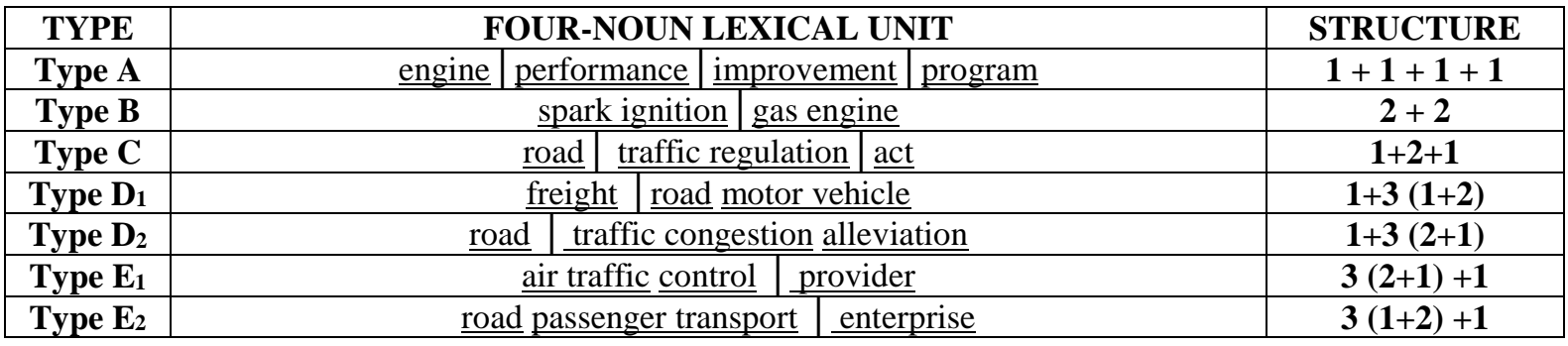

Type $A$ is the simplest type of four-noun lexical units. Interpreting starts from the head noun in the reversed order. Each of the nouns is a separate semantic unit for itself:

$$
\begin{aligned}
& \begin{array}{llll}
1 & 2 & 3 & 4
\end{array} \\
& \text { engine } \mid \text { performance }|\underline{\text { improvement }}| \text { program }= \\
& 1+1+1+1
\end{aligned}
$$

Type B. Identifying semantic units seems easier than in types C, D or E. The example that follows features two two-noun lexical units (semantic units) spark ignition and gas engine in which the head nouns (ignition in the first one, and engine in the second one) are tightly bonded to their premodifiers (spark in the first one, and gas in the second one). Adhering to the rules of indivisibility of semantic units and decoding from the head noun leftwards, the paraphrase is as follows:

$$
\begin{array}{llll}
1 & 2 & 2
\end{array}
$$

spark ignition $\mid$ gas engine $=$ a gas engine $($ which is) started by spark ignition

$2+2$

Type $C$. In the example that follows the head noun act is directly premodified by a two-noun lexical unit traffic regulation which is in turn premodified by a noun road. Nouns (semantic units) road and act are more loosely attached:

$$
\begin{array}{llllll}
1 & 2 & 3 & 3 & 2 & 1
\end{array}
$$

road $\mid$ traffic regulation $\mid \underline{\text { act }}=$ the act on/regarding traffic regulation on the road

$1+2+1$

Type $D_{l}$. As seen in the following example, semantic relationship among the nouns in a four-noun lexical unit may be such that the head noun vehicle embedded in the two-noun lexical unit motor vehicle is as a whole premodified by a noun road, forming with it a semantic unit (three-noun lexical 
unit) road motor vehicle, which is in turn premodified by the noun freight, more loosely attached at the initial position:

$\underline{\text { freight }} \mid \underline{\text { road }} \underline{\text { motor vehicle }}=$ a road motor vehicle $($ exclusively) designed to carry freight

$$
1+3(1+2)
$$

Type $D_{2}$. As the following example illustrates, the last noun, starting from right leftwards, road premodifies a three-noun lexical unit traffic congestion alleviation consisting of the head noun alleviation premodified by a two-noun lexical unit traffic congestion:

$$
\begin{array}{llll}
1 & 2 & 2 & 1
\end{array}
$$

road $\mid \underline{\text { traffic congestion alleviation }=\text { the alleviation of traffic congestion on the roads }}$

$$
1+3(2+1)
$$

In both types, $\mathrm{D}_{1}$ and $\mathrm{D}_{2}$, the last noun, as seen from right leftwards, premodifies a three-noun lexical unit with the difference that in the first case $\left(D_{1}\right)$ the three-noun lexical unit consists of a two-noun lexical unit premodified by a single noun, while the other one $\left(D_{2}\right)$ consists of a head noun premodified by a two-noun lexical unit.

Type $E_{1}$. The head noun in a four-noun lexical unit (provider) can be premodified by a three-noun lexical unit (air traffic control) that consists of the head noun (control) premodified by a two-noun lexical unit (air traffic), as seen in the following example:

$$
\begin{array}{c|ccc}
1 & 2 & 2 & 1 \\
\frac{\text { air traffic control }}{3(2+1)}+ & \begin{array}{l}
\text { provider } \\
\text { the throvider of }
\end{array} \text { air traffic control }
\end{array}
$$

Type $E_{2}$. This structural type features the head noun enterprise premodified by a three-noun lexical unit (road passenger transport) that consists of the two-noun lexical unit (passenger transport) premodified by a noun road:

$$
12 \quad 2 \quad 1
$$

road passenger transport $\mid$ enterprise $=$ an enterprise engaged in the road passenger transport

$$
3(1+2)+1
$$

Task 1:

Determine the structural types of the following four-noun lexical units:

e.g. $\quad$ train $\mid$ motive power $\mid$ type

air traffic control centre

traffic infrastructure development plan

person's blood alcohol content

Task 2: Having mastered the underlying structural parts of four-noun lexical units, students can proceed with paraphrasing the same examples from the previous task.

Task 3: Selecting the correct paraphrase using MCQ is suggested as next classroom activity.

Choose the correct paraphrase of the following four-noun lexical units:
e.g. diesel engine fuel consumption
a) the engine consumption caused by a diesel fuel
b) the fuel consumption of a diesel engine
c) the engine fuel used for diesel consumption
d) the consumption of a diesel engine caused by fuel

\subsection{Teaching and Learning MNLUs Production Strategies}

After students had learnt the underlying principles of MNLUs reception, they are ready to start producing them. The suggestion is to teach them MNLU production learning strategies immediately after they have mastered the reception strategies of each of the structural types (from two-noun 
lexical units to four-noun lexical units).

Literature review on MNLUs production learning strategies reveals only one author (Master 2003) offering just one type of the exercise for this purpose. The author proposes the production of MNLUs from paraphrases (definitions) given in the context:

The material for insulation that is made from formaldehyde burned rapidly, releasing toxic fumes. = Formaldehyde insulation material ...

This type of exercise should be used extensively, especially when we come across a paraphrased MNLU in teaching materials (texts) the students should be asked to produce a MNLU. However, for the practicing purpose, we suggest decontextualized MNLUs production as well, as shown in the following tasks.

Task 1:

We propose this type of exercise which is more student-friendly than the previous one, for it clearly suggests the number of nouns to be used.

Produce a MNLU out of the offered paraphrase. The number of lines corresponds to the number of nouns you can use:

an accident that happens in traffic $=$

a nozzle used for the injection of fuel $=$

the evaluation of traffic safety performance $=$

Task 2:

L1 should not be excluded from an ESP classroom. Students can be provided by a lexical unit in their mother tongue (L1) and asked to produce an English equivalent MNLU. English nouns are arranged in alphabetical order to facilitate the task yet avoiding suggestions regarding the order. In the following example Croatian is used as L1:

Based on the meaning of lexical units in your mother tongue, produce English MNLU equivalents. Use the nouns in brackets arranged in alphabetical order:

e.g. poduzeće za cestovni prijevoz putnika

passenger road transport enterprise

$\overline{\text { (enterprise }} \overline{\text { passenger }} \overline{\text { road }}$

a) uređaj za gašenje pjenom

(extinguisher foam)

b) zonska kontrola prometa

$\overline{\text { (area }} \overline{\text { control }}-\overline{\text { traffic })}$

Task 3:

This task is more difficult than the previous one, since it requires more profound knowledge of the field. Nouns are offered in randomized order without offering MNLUs' translation equivalent in L1.

Produce MNLUs in English by stringing the nouns in correct order:

e.g. driving style individual = individual driving style

tank fuel $=$

system control scale $=$

motor standards vehicles safety $=$

\section{CONCLUSION}

One of the central issues in teaching ESP is to help students achieve lexical competencies as similar as those of native speakers, users of various technical registers. In order to achieve this goal, students at tertiary education level should master reception and production of MNLUs, since they are exposed to 
them in specialized written texts. Their ESP teachers are generally faced with the problem od absence of readily made materials for the purpose. Since the English language allows a complex premodification of nouns, in which there is a sequence of nouns without functional words helping in reception, i.e. recognition of semantic links among the constituent nouns, students struggle to make sense out of these noun clusters. This paper is an aid to ESP teachers and learners in mastering the basic principles of reception and production of MNLUs, proposing teaching and learning strategies and lexical exercise types. It summarizes the theory and teaching experience in relation to MNLUs, gradually developing ways to their reception and production. Students need to be made aware of MNLUs, helped to identify, receive (interpret), practice and produce them. The task of ESP teachers is to offer students different learning strategies, being aware and making their students aware that there are no unambiguous, generally accepted and clear rules of MNLUs reception and production. Learning the strategies cannot guarantee the undoubtedly correct reception or production, yet it will help eliminating syntactic errors. The complete understanding requires knowledge of the subject matter which in part-time students already working in the profession can be more extensive than the knowledge of their ESP teachers.

And finally, as Master (2003) says, students should be warned not to feel helpless and frustrated when they come across MNLUs that they do not understand, as it is very likely that their ESP teacher does not understand them either. Moreover, it is comforting to know that even native speakers, not acquainted with a particular professional field, feel confused in the encounter with MNLUs as well.

\section{REFERENCES}

[1] Hutchinson, T. and Waters, A. (1987). English for Specific Purposes. Cambridge: Cambridge University Press.

[2] Carver, D. (1983). Some propositions about ESP. The ESP Journal 2, 131-137.

[3] Strevens, P. (1988). ESP after twenty years: Are-appraisal. ESP: State of the Art, 1-13.

[4] Dudley-Evans, T. and St John, M. J. (1998). Developments in English for Specific Purposes: A Multidisciplinary Approach. Cambridge: Cambridge University Press.

[5] Halliday, M. A. (1985). An Introduction to Functional Grammar. London: Arnold.

[6] Kvam, A. M. (1990). Three-part noun combinations in English, composition-meaning-stress. English studies 71 (2), 152-161.

[7] Stambuk, A. (1997). Multi-word lexical units in English and Croatian terminology of electronics. Studia romanica et anglica Zagrabiensia 42, 373-389.

[8] Fabb, N. (1998). Compounding. In A. Spencer i A. M. Zwicky (ed.), The Handbook of Morphology. Oxford: Blackwell, 66-83.

[9] Huddleston, R. and Pullum, G. K. (2010). A Student's Introduction to English Grammar. [6 $6^{\text {th }}$ edition]. Cambridge: Cambridge University Press.

[10] Zgusta, L. (2010). Manual of lexicography (Vol. 39). Walter de Gruyter.

[11] Spiranec, I. (2011). Viseclani nazivi u engleskom gradjevinskom nazivlju s posebnim osvrtom na imenske slozenice (Doctoral dissertation. Doktorska disertacija). Filozofski fakultet Sveucilista u Zagrebu.

[12] Leech, G. and Svartvik, J. (2013).A Communicative Grammar of English. [ $3^{\text {rd }}$ edition]. London: Routledge.

[13] Fercec, I. and Liermann-Zeljak, Y. (2015). Nominal compounds in technical English. In A. Akbarov (ed.), The Practice of Foreign Language Teaching: Theories and Applications. Newcastle Upon Tyne: Cambridge Scholars Publishing, 268-277.

[14] Limaye, M. and Pompian, R. (1991). Brevity versus clarity: The comprehensibility of nominal compounds in business and technical prose. Journal of Business Communication 28 (1), 7-21.

[15] Izquierdo, B. Leiva de and Bailey, D. (1998). Complex noun phrases and complex nominals: Some practical considerations. TESL Reporter31 (1), 19-29.

[16] Master, P. (2003). Noun compounds and compressed definitions. English Teaching Forum 41(3), 2-9.

[17] Master, P. (2004). English Grammar and Technical Writing. Washington, D.C.: United States Department of State, Office of English Language Programs.

[18] CarrióPastor, M. L. (2008). English complex noun phrase interpretation by Spanish learners. RESLA21, 27-44.

[19] Kerekovic, S. (2012). Viserjecni nazivi u tehnickome engleskom jeziku i njihove prijevodne istovrijednice u hrvatskome jeziku. (Doctoral dissertation. Doktorska disertacija). Filozofski fakultet, Sveuciliste u Zagrebu.

[20] Newmark, P. (1985). The Application of Case Grammar to Translation. Trier: Linguistic Agency, University of Trier. 
[21] Polić, T. (2019). Predmodifikacija imenica u viserjecnim nazivima u nastavi engleskoga jezika prometnih struka. (Doctoral dissertation. Doktorska disertacija). Filozofski fakultet, Sveuciliste u Zagrebu.

[22] Ministry of Science and Education of the Republic of Croatia (2006). Elementary school curriculum. The Croatian language. (Official Gazette 102/2006). Retrieved on August 23 ${ }^{\text {rd }}$, 2017, from http://narodnenovine.nn.hr/clanci/sluzbeni/dodatni/129147.htm.

[23] Lindell, A. K. (2006). In your right mind: Right hemisphere contributions to language processing and production. Neuropsychology review, 16(3), 131-148.

[24] Shehata, A. K. (2008). L1 influence on the reception and production of collocations by advanced ESL/EFL Arabic learners of English (Doctoral dissertation). Ohio University.

[25] Dziemianko, A. (2010). Paper or electronic? The role of dictionary form in language reception, production and the retention of meaning and collocations. International Journal of Lexicography, 23(3), 257-273.

[26] Spinner, P. (2013). Language production and reception: A Processability Theory study. Language Learning, 63(4), 704-739.

[27] Nicholls, G. H., and Mcgill, D. L. (1982). Cued Speech and the reception of spoken language. Journal of Speech, Language, and Hearing Research, 25(2), 262-269.

[28] Milner, J. O. and Milner Elrod, M. (1986). Language reception in three modes. The Journal of geneticpsychology, 147(1), 123-133.

[29] Pastor Góméz, I. (2010). Nominal Modifiers in Noun Phrase Structure: Evidence from Contemporary English. Univ Santiago de Compostela.

[30] Nakov, P. (2013). On the interpretation of noun compounds: Syntax, semantics, and entailment. Natural Language Engineering, 19(3), 291-330.

[31] Lewis, M. (1993). The Lexical Approach: The State of ELT and the Way Forward. Hove: Language Teaching Publications.

[32] Gacic, M. (2009). Gramatika engleskoga jezika struke. Zagreb: Uciteljski fakultet Sveucilista u Zagrebu and Skolska knjiga d.o.o.

[33] Biber, D., Johansson, S., Leech, G., Conrad, S., Finegan, E. and Quirk, R. (1999). Longman Grammar of Spoken and written English (Vol. 2). London: Longman.

[34] Bartolic, L. (1979). Imenske slozenice u tehnickom engleskom jeziku. Strani jezici 8(1-2), 47-58.

[35] Skaric, O. (1989). Transparentnost naslova tekstova gradjevinske struke. Strani jezici 18 (1), 27-36.

[36] Bartolic, L. (1978). Nominal compounds in technical English. English for specific purposes: Science and technology, 257-277.

[37] Kovacevic, M., Palmovic, M., and Hrzica, G. (2009). The acquisition of case, number and gender in Croatian. Development of nominal inflection in first language acquisition: A cross-linguistic perspective, 153-177.

[38] Stambuk, A. (2005). Jezik struke i spoznaja. Split: Knjizevni krug.

[39] Warren, B. (1978). Semantic Patterns of Noun-Noun Compounds. (Doctoral dissertation.). University of Gothenburg.

\section{AUTHOR'S BIOGRAPHY}

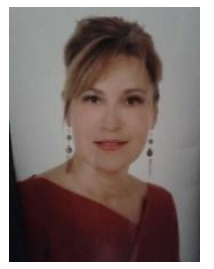

Tamara Polić, PhD is a Senior Lecturer at the Polytechnic of Rijeka, Croatia. She teaches English for Traffic and Transport Purposes and Business English. Obtained her $\mathrm{PhD}$ degree in Glottodidactics (Foreign Language Teaching - FLT) from the Faculty of Humanities and Social Sciences, University of Zagreb, Croatia.

Citation: Tamara Polić. "Teaching Multi-Word Lexical Units in English for Specific Purposes" International Journal on Studies in English Language and Literature (IJSELL), vol 8, no. 6, 2020, pp. 26-37. doi: http://dx. doi .org/10.20431/2347-3134.0806004.

Copyright: (C) 2020 Authors. This is an open-access article distributed under the terms of the Creative Commons Attribution License, which permits unrestricted use, distribution, and reproduction in any medium, provided the original author and source are credited. 